\title{
Seasonal changes in the standing stocks, growth rates, and production rates of gelatinous predators in Saanich Inlet, British Columbia
}

\author{
R. J. Larson \\ Department of Biology, University of Victoria, Victoria, British Columbia V8W 2Y2, Canada
}

\begin{abstract}
Thirty-three species of gelatinous predators (medusae and ctenophores) were collected in the uppermost $25 \mathrm{~m}$ of Saanich Inlet over 3 spring seasons. Of these, 6 species (5 hydromedusae: Aequorea victoria, Aglantha digitale, Mitrocoma cellularia, Phialidium gregarium, and Phialidium lomae; and 1 ctenophore: Pleurobrachia bachel comprised more than $90 \%$ of the total gelatinous predator biomass. $P$. bachei comprised $40 \%$ of the total dry weight of gelatinous predators, with peak standing stocks reaching $100 \mathrm{mg} \mathrm{DW} \mathrm{m} \mathrm{m}^{-3}\left(-5 \mathrm{mg} \mathrm{C} \mathrm{m}^{-3}\right)$. Phialidium spp. formed $20 \%$ of the total dry weight, with $P$. gregarium reaching a maximum value at 1 station of about $200 \mathrm{mg} \mathrm{DW} \mathrm{m}^{-3}(\sim 20 \mathrm{mg} \mathrm{C}$

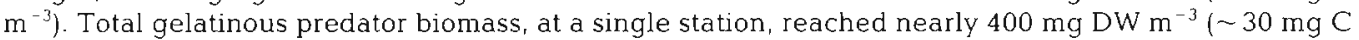
$\mathrm{m}^{-3}$ ) in late May. A conservative estimate of net yearly production in the upper $25 \mathrm{~m}$ is 6 to $10 \mathrm{mg} \mathrm{C}$ $\mathrm{m}^{-3}$. Standing stocks of individual species had doubling times of 5 to $17 \mathrm{~d}$. Food supply (mainly the abundance of euphausiid eggs), coupled with temperature, were probably the primary factors regulating growth and production.
\end{abstract}

\section{INTRODUCTION}

Seasonal changes in the species composition and biomass of zooplankton are of considerable importance when interpreting dynamic events within the plankton. However, most of this work has centered on herbivores and has ignored planktonic predators, resulting in a biased view of pelagic food webs. Gelatinous predators (i.e. meduase, siphonophores, and ctenophores) are one group for which temporal variations in the biomass are poorly known. This is primarily because these predators are fragile, occur at low densities (relative to copepods), and are sometimes difficult to preserve and identify. Most of the studies on temporal changes in gelatinous predator biomass and production have been limited to only a few species (i.e. Aurelia aurita, Mnemiopsis spp., and Pleurobrachia spp.). Because of this, it is difficult to conclude how important gelatinous predators are worldwide. Therefore a study of gelatinous predator standing stocks, growth, production rates, and possible regulating fac-

Present address: Harbor Branch Institution, RR 1, Box 196-A, Fort Pierce, Florida 33450, USA tors, was undertaken in Saanich Inlet, British Columbia, where a number of species of medusae and ctenophores are seasonally very abundant (Huntley \& Hobson 1978, Mills 1982).

The physical oceanography of Saanich Inlet and adjacent waters is treated in detail by Herlinveaux (1962), Pickard (1961), Thomson (1981), and LeBlond (1983). Temperatures in the upper $25 \mathrm{~m}$ show a sinusoidal seasonal pattern, with an average winter minimum of $\sim 8^{\circ} \mathrm{C}$ in January-February, and thereafter slowly rising to an average summer maximum of $\sim 12$ to $13^{\circ} \mathrm{C}$ in July-August. For short periods during the summer when irradiation is high and there is little wind, surface temperatures can reach 20 to $22^{\circ} \mathrm{C}$.

There is little runoff into Saanich Inlet; consequently, salinities in the upper $25 \mathrm{~m}$ remain relatively stable at 28 to 29 ppt for most of the year, and estuarine circulation is weakly developed. Tidal currents are also relatively slight owing to the shape of the inlet. As a result, surface plankton populations probably oscillate back and forth with the tides. Nonetheless, down-inlet winds can cause surface waters (and presumably plankton) to move out of the inlet (Hobson pers. comm. 1985). 


\section{METHODS}

Standing stocks of medusae, ctenophores, and mesozooplankton were determined in Saanich Inlet, British Columbia over 3 spring seasons (1980, 1981, and 1983). Replicate vertical plankton tows were made ( 0 to $25 \mathrm{~m}$ ) between 1200 and $1600 \mathrm{~h}$ at 4 stations in 1980 and 1981, using $50 \mathrm{~cm}$ diameter nets $(0.3 \mathrm{~mm}$ and $0.7 \mathrm{~mm}$ mesh size). Because of the apparent abundance of medusae and ctenophores in the upper $5 \mathrm{~m}$ a plankton trap ( $0.3 \mathrm{~m}^{3}$ sample volume, $0.2 \mathrm{~mm}$ mesh) (Larson 1985) was specially designed to sample at shallow depths. In 1983, 4 to 7 replicate samples using the plankton trap were taken in the upper $5 \mathrm{~m}$ at a single station.

Samples were fixed in $5 \%$ formalin and later enumerated in the laboratory. Gelatinous predators were counted from whole samples. Mesozooplankton were counted from subsamples containing at least 100 specimens. For mesozooplankton, the coefficient of variation between subsample counts was $19 \pm 3$ (mean \pm standard error), for replicate hauls it was $31 \pm 3$.

The biomass of gelatinous predators was estimated from length versus dry weight and carbon \% dry weight relations (Larson 1986). Mesozooplankton biomass was estimated from subsample counts and published carbon values for major species. Biomass values for both gelatinous predators and mesozooplankton were averaged for all stations, since there were no significant differences among standing stock data (tested using ANOVA).

The coefficient of daily exponential population biomass increase $(\mathrm{K})$ was calculated from changes in biomass with time (i.e. $\mathrm{K}=1 / \mathrm{T}$ Ln $\left[\mathrm{W}_{\mathrm{t}} / \mathrm{W}_{0}\right]$, where $\mathrm{Ln}=$ natural $\log , \mathrm{T}=$ time period, $\mathrm{W}_{\mathrm{L}}=$ biomass at time $\mathrm{T}, \mathrm{W}_{0}=$ initial biomass). In situ growth rates were estimated anly from changes in mean sizes with time (recruitment or mortality were not considered). A minimum estimate of net production was determined from the change in standing stocks with time since cohorts were not evident (mortality and reproduction were not accounted for)

\section{RESULTS}

A total of 33 species of gelatinous predators were collected in the upper $25 \mathrm{~m}$ of Saanich Inlet. These included: hydromedusae (25 species), scyphomeduase (2 species), ctenophores ( 4 species), and siphonophores (2 species). However, only 5 medusae (Aequorea victoria, Aglantha digitale, Mitrocoma cellularia, Phialidium gregarium, and Phialidium lomae) and 1 ctenophore (Pleurobrachia bachei) comprised more
Table 1 List of major gelatinous predators and \% of total biomass contribution, for 1980-81 data

\begin{tabular}{|lcc|}
\hline \multicolumn{1}{|c}{ Taxon } & \% Total & Biomass \\
& C & DW \\
\hline Pleurobrachia bachei & 39.4 & 39.3 \\
Phialidium spp. & 36.4 & 22.7 \\
Aequorea victoria & 8.4 & 24.6 \\
Mitrocoma cellularia & 4.0 & 6.7 \\
Aglantha digitale & 3.8 & 1.2 \\
Sarsia spp. & 1.8 & 1.3 \\
Stomotoca atra & 1.8 & 0.9 \\
Mitrocomella polydiademata & 1.2 & 0.9 \\
Eutonina indicans & 1.3 & 0.7 \\
Proboscidactyla flavicirrata & 0.7 & 0.5 \\
Muggiaea atlantica & 0.4 & 0.6 \\
Euphysa spp. & 0.5 & 0.3 \\
Bougainvillia multitentaculata & 0.3 & 0.2 \\
\end{tabular}

than $90 \%$ of the total gelatinous predator biomass (Table 1).

\section{Seasonal changes in biomass of major gelatinous predators}

Pleurobrachia bachei, a ctenophore, was a dominant species in many samples. In 1980-81, P. bachei ranked first in biomass. Although present in the plankton year-round, its highest biomass was observed in late spring and early summer (Fig. 1 \& 2). Most of the growth and production of $P$. bachei occurred in spring. In April, small individuals $(<3 \mathrm{~mm})$ predominated. However by the end of May, large specimens (10 to $17 \mathrm{~mm}$ dia.) were common, with mean diameters reaching $>8 \mathrm{~mm}$ (Fig. $3 \& 4$ ). Mean sizes were small throughout the summer and fall (and probably in the winter as well), when no significant growth or production occurred (Fig, 4).

In 1980-81, Phialidium gregarium and Phialidium lomae were tallied together because it was not realized, until 1981, that 2 Phialidium spp. were present. However in 1983, they were separately enumerated. Together, they ranked 2nd in overall biomass. Although they probably occur year-round, at least in small numbers, they were most abundant in spring and early summer. Small Phialidium spp. medusae occur in the plankton almost year-round, but most recruitment into the plankton occurs in spring and summer, as suggested by the large numbers of small medusae ( $<5 \mathrm{~mm}$ ) present then (Fig. 5). Mean individual bell diameters increased from $3 \mathrm{~mm}$ in April 1981 to $16 \mathrm{~mm}$ by June 1981 (Fig. 4). Spring recruits were most successful at reaching larger sizes; summer recruits showed little increase in size. Thus, most production occurs in the spring. 

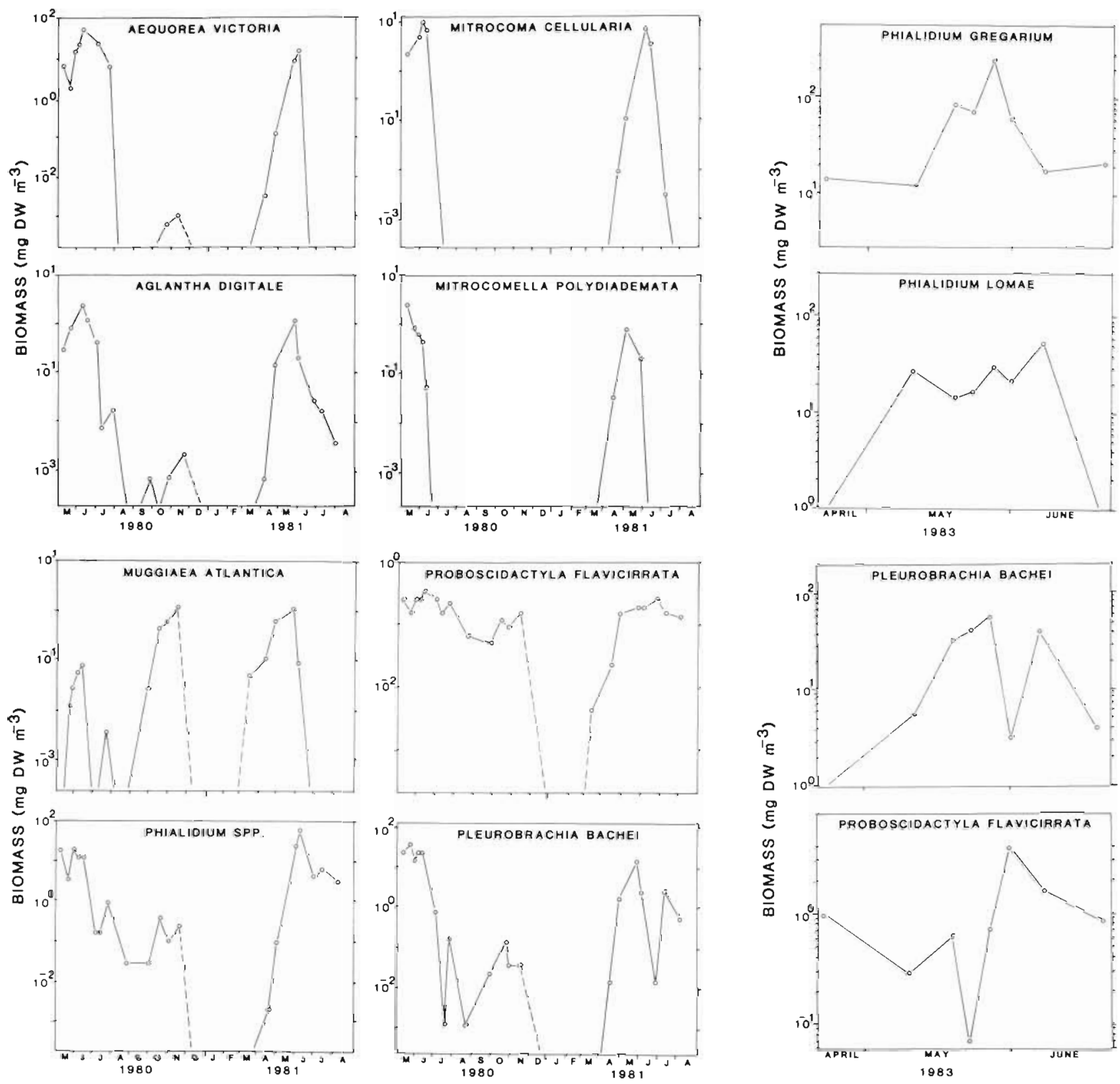

Fig. 1. Temporal changes in biomass for Aequorea victoria, Aglantha digitale, Mitrocoma cellulania, and Mitrocomella polydidaemata, Muggiaea atlantica, Phialidium spp. (P. gregarium + P. lomae), Proboscidactyla flavicirrata, and Pleurobrachia bachei (1980-81; 0 to $25 \mathrm{~m}$ ). Dashed line: suspected change

Fig. 2. Temporal changes in biomass for Phialidium gregarium, Phialidium lomae, Proboscidactyla flavicirrata, and Pleurobrachia bachei (1983; 0 to $5 \mathrm{~m}$ )

Aequorea victoria, the largest hydromedusa in Saanich Inlet (reaching $>6 \mathrm{~cm}$ in diameter), ranked 3 rd in overall biomass. Only a single period of recruitment of juvenile medusae into the plankton appeared to take place, in early spring. By midsummer, adults (>30 mm) predominated. This medusa was seen on many occasions to be feeding on other medusae and on Pleurobrachia bachei.

Mitrocoma cellularia. the 2nd largest hydromedusa (up to $\sim 6 \mathrm{~cm}$ in diameter) in Saanich Inlet, ranked 4 th in overall total biomass for 1980-81 samples. $M$. cellularia was present mostly in the spring. In 1981. there were many moribund (probably heat-killed) $M$. cellularia at the surface of Saanich Inlet where temperatures measured $22^{\circ} \mathrm{C}$.

Aglantha digitale ranked 5 th in overall total biomass, accounting for $1 \%$ of the total dry weight but $4 \%$ of the carbon. It is present year-round in deep water (Mills 1982) but was most abundant near the surface in late spring as juveniles. Small specimens 


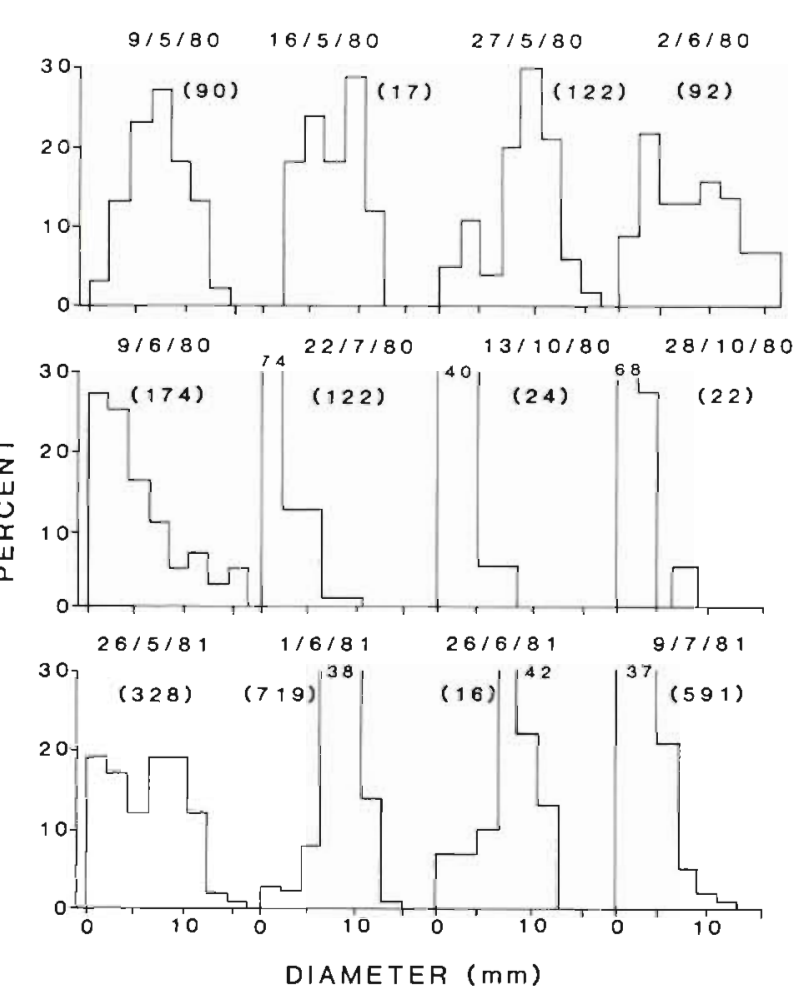

Fig. 3. Pleurobrachia bachei. Size frequency diagram

predominated in daytime hauls in the upper $25 \mathrm{~m}$. In 1980 , after the main recruitment of $A$. digitale juveniles in the spring, a 2nd group of juveniles appeared in July, but they either did not grow or else they migrated to greater depths. A 3rd group of juveniles appeared in November, but their fate was undetermined.

Other less important gelatinous predators included the hydromedusae Sarsia spp., Stomotoca atra, Mitrocomella polydiademata, Eutonina indicans, Proboscidactyla flavicirrata, Euphysa spp., and Bougainvillia multitentaculata, and the siphonophore Muggiaea atlantica. Most of these species occurred only during the spring (Fig, 1 \& 2); exceptions were P. flavicirrata which was present at a low biomass almost year-round (Fig. 1) and $M$. atlantica which had both spring and fall biomass maxima (Fig. 1).

\section{Total gelatinous predator standing stocks}

Total biomass values for gelatinous predators in 1980 and 1981 were comparable, reaching maximum values in late May to early June of both years (Fig. 6). In 1980, the highest values were mostly due to Aequorea victoria, Pleurobrachia bachei, and Phialidium spp.; while in 1981, values were mostly due to $P$. bachei. In 1983, biomass values attained maxima

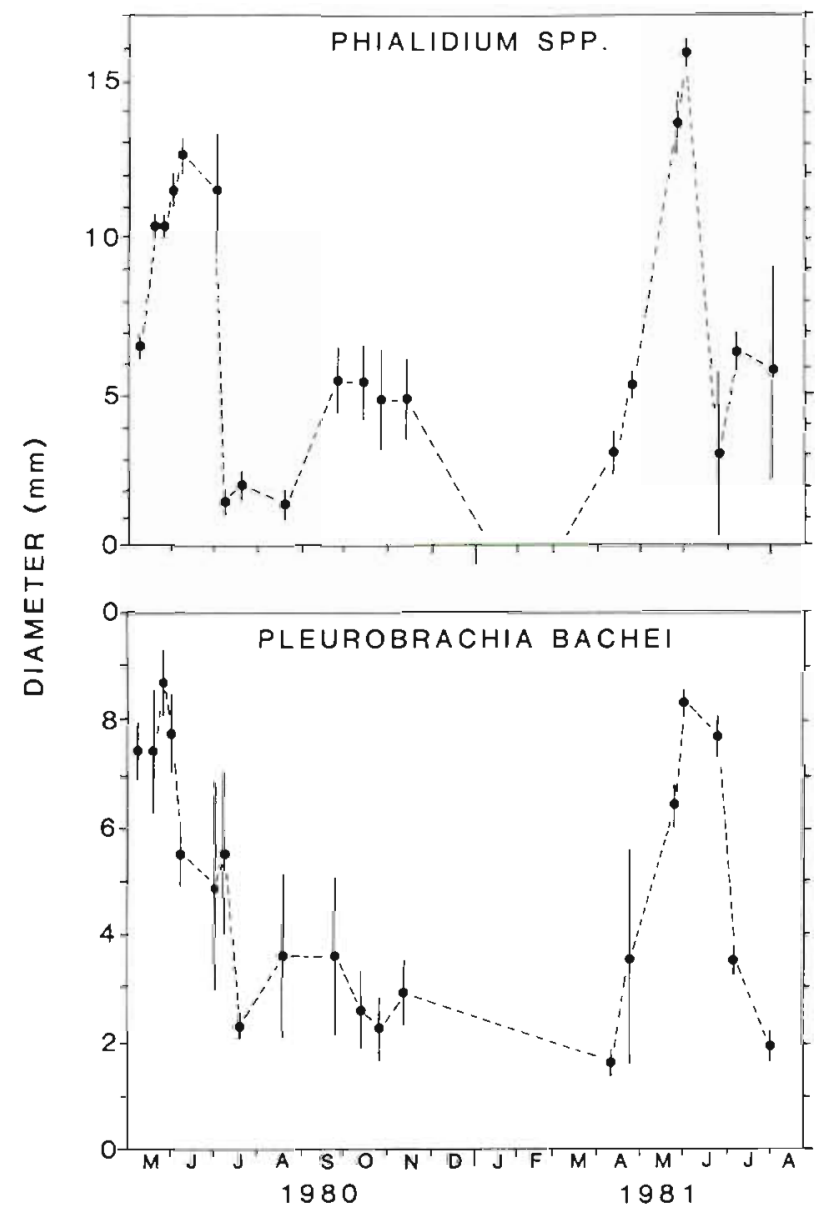

Fig. 4. Temporal changes in the bell diameter of Phialidium spp. ( $P$. gregarium $+P$. lomae), and of the oral-aboral diameter of Pleurobrachia bachei (mean and SE)

near the end of May and were mostly due to Phialidium spp. medusae (Fig. 6). Changes in the numerical abundance of gelatinous predators generally were accompanied by an increase or decrease in biomass, except during July-August when there were sometimes large numbers of juveniles with a low biomass.

\section{Gelatinous predator growth rates (population biomass and individual size)}

The coefficient of daily population biomass increase (K) ranged from 0.05 to 0.2 (Table 2), indicating that stocks doubled in 5 to $7 \mathrm{~d}$ (mortality was not accounted for, therefore these are minimum rates).

Mean in situ growth rates of Pleurobrachia bachei and Phialidium spp. averaged 0.1 to $0.2 \mathrm{~mm} \mathrm{~d}^{-1}$ or $0.2 \mathrm{mg} \mathrm{DW} \mathrm{d} \mathrm{d}^{-1}$ (Fig. 4) (note: since juveniles were entering the populations, these growth rates are minimal). 


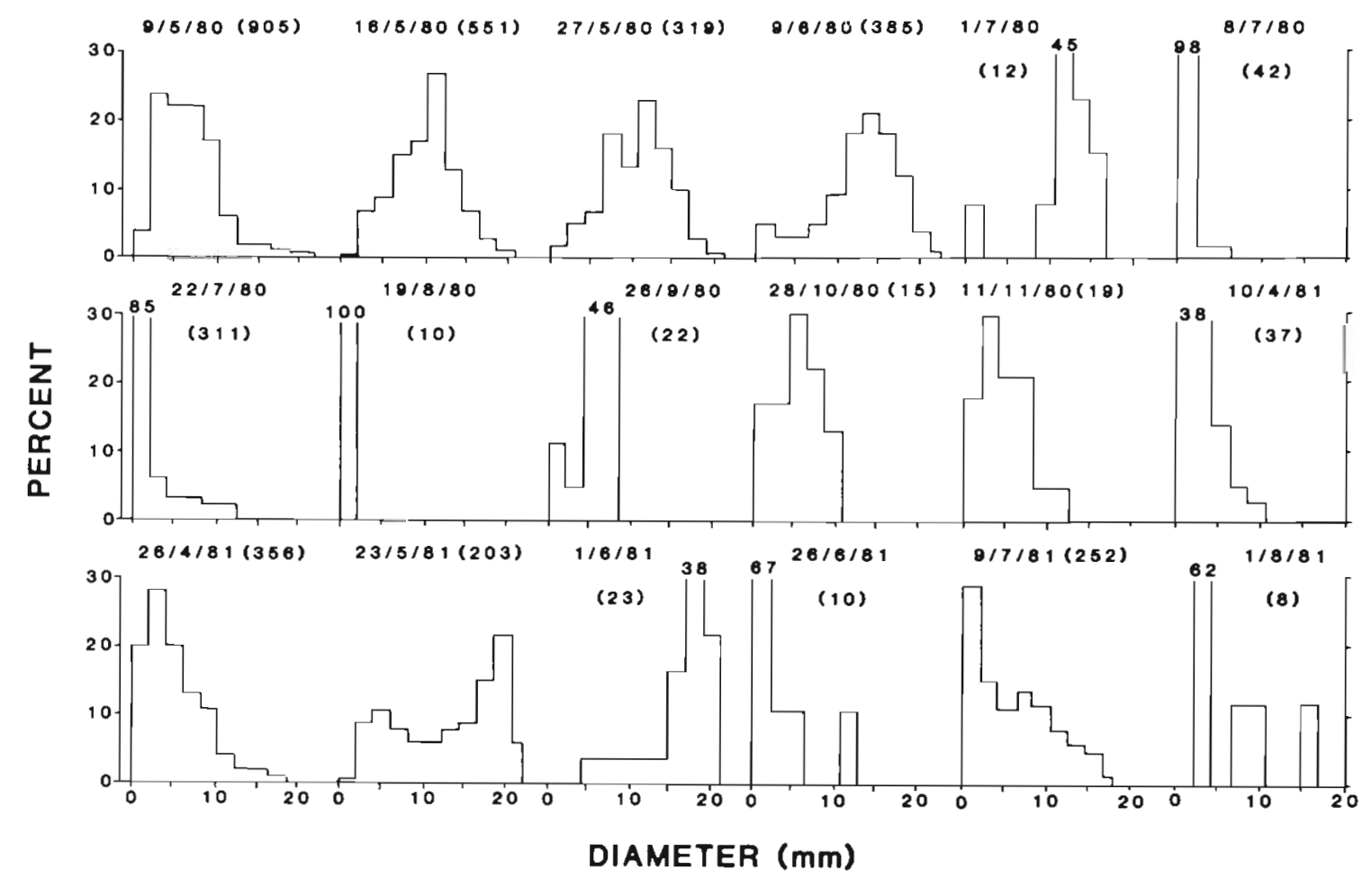

Fig. 5. Phialidium spp. (P. gregarium + P. lomae). Size frequency diagram

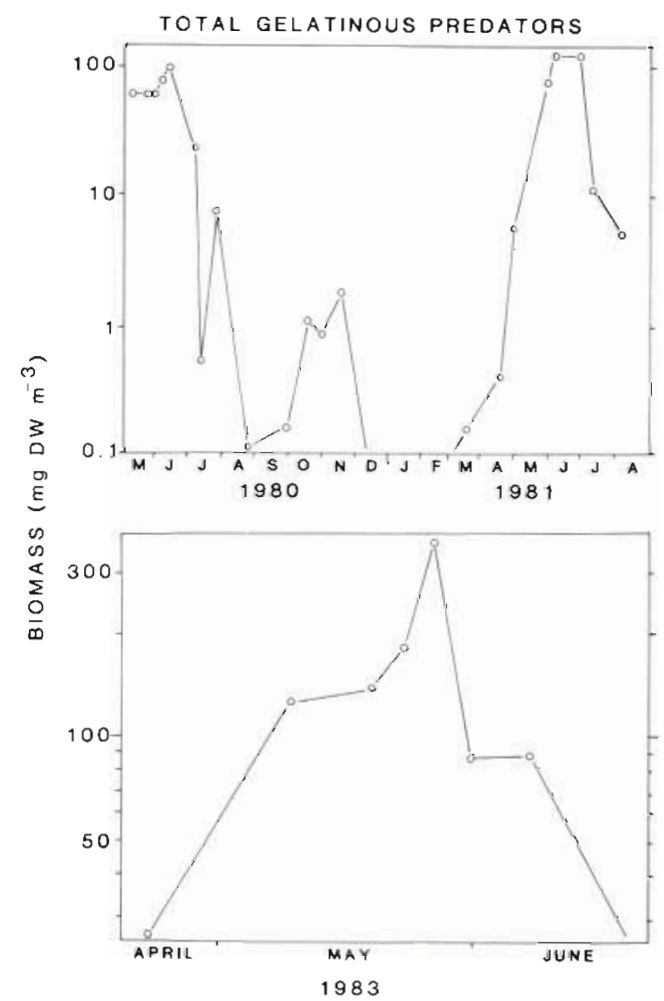

Fig. 6. Temporal changes in biomass for total gelatinous predators $1980-81,1983$
Table 2. Coefficients of daily population biomass increase (K) for gelatinous predators in Saanich Inlet. See text for formula

\begin{tabular}{|lll|}
\hline \multicolumn{1}{c}{ Taxon } & Dates & $\mathrm{K}$ \\
\hline Aglantha digitale & May-Jun 80 & 0.13 \\
Aglantha digitale & Apr-May 81 & 0.09 \\
Aequorea victoria & May-Jun 80 & 0.14 \\
Aequorea victoria & Apr-Jun 81 & 0.15 \\
Bougainvillia & & \\
multitentaculata & Apr-May 81 & 0.06 \\
Euphysa tentaculata & Mar-Apr 81 & 0.04 \\
Muggiaea atlantica & Sep-Nov 80 & 0.08 \\
Muggiaea atlantica & Apr-May 81 & 0.09 \\
Mitrocoma cellularia & Apr-May 81 & 0.16 \\
Pleurobrachia bachei & Apr-Jun 81 & 0.21 \\
Proboscidactyla & & \\
flavicirrata & Mar-Apr 81 & 0.09 \\
Phialidium spp. & Apr-May 81 & 0.17 \\
Stomotoca atra & Apr-Jun 81 & 0.08 \\
Total gel. predators & Apr-Jun 81 & 0.11 \\
\hline
\end{tabular}

\section{Gelatinous zooplankton net production}

Total gelatinous zooplankton net production reached at least 0.4 to $0.5 \mathrm{mg} \mathrm{C} \mathrm{m}^{-3} \mathrm{~d}^{-1}$ in May-June for all $3 \mathrm{yr}$ investigated (Fig. 7) (mortality was not taken into account). Total seasonal net production 

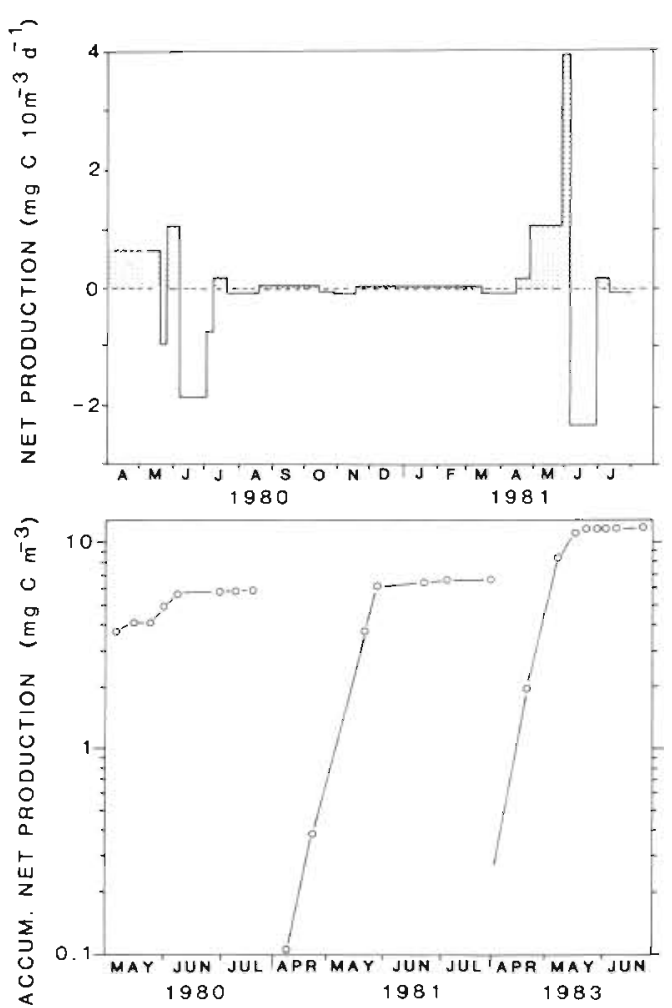

Fig. 7. Total net production by gelatinous predators. Top: daily production (1980-81). Stippled area: positive production. Bottom: accumulative production $(1980,1981,1983)$

(April to July) for the upper $25 \mathrm{~m}$ was approximately $6 \mathrm{mg} \mathrm{C} \mathrm{m} \mathrm{m}^{-3}$ for 1980 and 1981. In 1983, seasonal production in the upper $5 \mathrm{~m}$ probably was near $10 \mathrm{mg}$ $\mathrm{C} \mathrm{m}^{-3}$ (actually, production based on peak biomass values would have been 3 times this value but this peak biomass value, measured at a single station, was probably due to physical factors [e.g. currents] rather than to a real biomass increase). Yearly values would be comparable since most production (>60\%) occurs between April and June (Fig. 7). Daily production/ mean biomass values $(\mathrm{P} / \mathrm{B})$ reached 0.04 to 0.1 ; yearly values would be equal to $\sim 5$ to 10 (assuming a mean biomass of $\sim 0.3$ to $0.8 \mathrm{mg} \mathrm{C} \mathrm{m}^{-3}$ ). For Pleurobrachia bachei, net production reached $0.6 \mathrm{mg} \mathrm{C} \mathrm{m}^{-3} \mathrm{~d}^{-1}$, and peak seasonal production was at least $7 \mathrm{mg} \mathrm{C} \mathrm{m}^{-3}$, with both occurring in 1981. Comparable production values were reached by Phialidium spp. in 1983 (Table 3).

\section{DISCUSSION}

\section{Possible sources of error}

It is difficult to compare the results of $1980-81$ with those of 1983 because 1980-81 samples were taken with a plankton net in the upper $25 \mathrm{~m}$ and 1983 samples were taken with a plankton trap in the upper $5 \mathrm{~m}$. Furthermore, owing to the small sample size of the plankton trap $\left(0.3 \mathrm{~m}^{-3}\right)$ the biomass of the species that occurred in low densities but with a high individual biomass (e.g. Aequorea victoria, Mitrocoma tellularia) could have been underestimated. Variability in length versus weight and in carbon \% dry weight values from season to season would also affect estimated biomass values. Production estimates are probably conservative because they do not take mortality and reproduction into account. However because gelatinous predators populations were dominated by juveniles, reproductive output was small (Larson in press). Growth rates are probably also conservative because they do not include mortality and recruitment.

A further source of error might be due to incomplete sampling of some gelatinous predator populations owing to broad depth ranges or vertical migrations. Mills (1982) and Mackie \& Mills (1983) found that most gelatinous predator species in Saanich Inlet occurred mainly between 0 and $25 \mathrm{~m}$, both day and night; however, some were restricted to greater depths. Aglantha digitata is a notable exception which undergoes an ontogenetic vertical migration, with juveniles found above $25 \mathrm{~m}$ and adults below $25 \mathrm{~m}$ (Arai \& Fulton 1973. Mills 1982). Data in Guest (1979) suggest that over $50 \%$ of the medusae and ctenophore biomass in the 0 to $120 \mathrm{~m}$ depth range occurs at depths of less than $30 \mathrm{~m}$. Thus the 0 to $25 \mathrm{~m}$ zone appears to have a distinctive and important gelatinous predator fauna.

Table 3. Net production by gelatinous predators in Saanich Inlet

\begin{tabular}{|c|c|c|c|c|c|}
\hline Taxon & $\begin{array}{l}\text { Max net production } \\
\quad\left(\mathrm{mg} C \mathrm{~m}^{3} \mathrm{~d}^{-1}\right)\end{array}$ & Date & $\begin{array}{l}\text { Total net production } \\
\qquad\left(\mathrm{mg} C \mathrm{~m}^{-3}\right)\end{array}$ & Dates & $\begin{array}{c}\text { Max daily } \\
\text { P/B }\end{array}$ \\
\hline Total gel. pred." & 0.1 & Jun 80 & 6 & May-Nov 80 & 0.04 \\
\hline Total gel. pred. & 0.4 & May 81 & 6 & Mar-Aug 81 & 0.06 \\
\hline Total gel. pred. & 0.5 & May 83 & -10 & Mar-Jul 83 & 0.1 \\
\hline Phialidium spp. & 0.5 & May 83 & 7 & Mar-Jul 83 & 0.1 \\
\hline Pleurobrachia bachei & 0.6 & May 81 & 6 & Mar-Jul 81 & 0.1 \\
\hline
\end{tabular}




\section{Temporal changes in gelatinous predator standing stocks}

Temporal changes in biomass of gelatinous zooplankton in the upper $25 \mathrm{~m}$ of Saanich Inlet were rapid and pronounced. Standing stocks ranged over 3 orders of magnitude, with winter standing stocks being only $0.1 \mathrm{mg} \mathrm{DW} \mathrm{m}^{-3}\left(\sim 0.5 \mathrm{mg} \mathrm{C} 100 \mathrm{~m}^{-3}\right)$ or less, whereas by May-June they reached $>100 \mathrm{mg} \mathrm{DW} \mathrm{m}^{-3}(>5 \mathrm{mg}$ $\mathrm{C} \mathrm{m}^{-3}$ ) (Huntley 1976, Guest 1979, this paper). Most of the change in the total standing stock took place between April $\left(\sim 1 \mathrm{mg} \mathrm{DW} \mathrm{m}^{-3}\right)$ and June (>100 $\mathrm{mg} \mathrm{DW}^{-3}$ $\mathrm{m}^{-3}$ ).

Significant changes can occur even more rapidly. For example, Huntley (1976) found that cnidarian/ ctenophore biomass increased a total of $80 \mathrm{mg} \mathrm{DW} \mathrm{m}^{-3}$ in just $2 \mathrm{wk}$. Guest (1979) showed a $400 \mathrm{mg} \mathrm{DW} \mathrm{m}^{-3}$ increase from mid-May to late June. Changes in stocks may be even greater for individual species. For example, Phialidium lomae biomass increased from 15 to $110 \mathrm{mg} \mathrm{DW} \mathrm{m}^{-3}$ in only $4 \mathrm{~d}$ (this paper).

Rapid declines in standing stocks also occur. In 1980 , a maximum gelatinous predator biomass of $110 \mathrm{mg}$ DW $\mathrm{m}^{-3}$ occurred in early June, yet just 1 mo later, had declined to only $0.5 \mathrm{mg} \mathrm{DW} \mathrm{m}^{-3}$. Most likely, some of these apparent changes were due to advective processes, especially in cases where data were collected only from a single station (Huntley 1976, Guest 1979, my data for 1983). However, where this change occurred at a number of stations (my data 1980-81), it probably reflects actual biomass changes. This is especially true in Saanich Inlet where advection of plankton populations is probably relatively small owing to weak estuarine and tidal circulation (Herlinveaux 1962).

\section{Factors affecting standing stocks}

Of the possible mechanisms that limit growth and production, food availability seems to be paramount. Support for the hypothesis that food levels are important in regulating the growth and production of gelatinous predators is given in the following observations: (1) numbers and standing stocks of gelatinous predators changed similarly to those of their prey, (i.e. lowest in winter, increasing in the spring, and reaching a maximum in May); (2) juvenile gelatinous predators were present for much of the year (e.g. Pleurobrachia bachei, Phialidium spp.), yet failed to show significant growth except during the spring when prey biomass was high. Larson (1985) reported that the major prey of gelatinous predators in the upper $25 \mathrm{~m}$ of Saanich Inlet was eggs of Euphausia pacifica. These eggs are mainly released in April-June (Heath 1977 , Larson 1985), during the period of maximum gelatinous predator production (Fig. 8). Additionally, an increase in temperature during the spring would raise metabolic rates and hence, food demand. By June-July the increase in temperature and the decrease in food availability may have led to population decreases in some predators. Other predators occurring near the surface may have actually been killed by thermal stress (e.g. Mitrocoma cellularia).

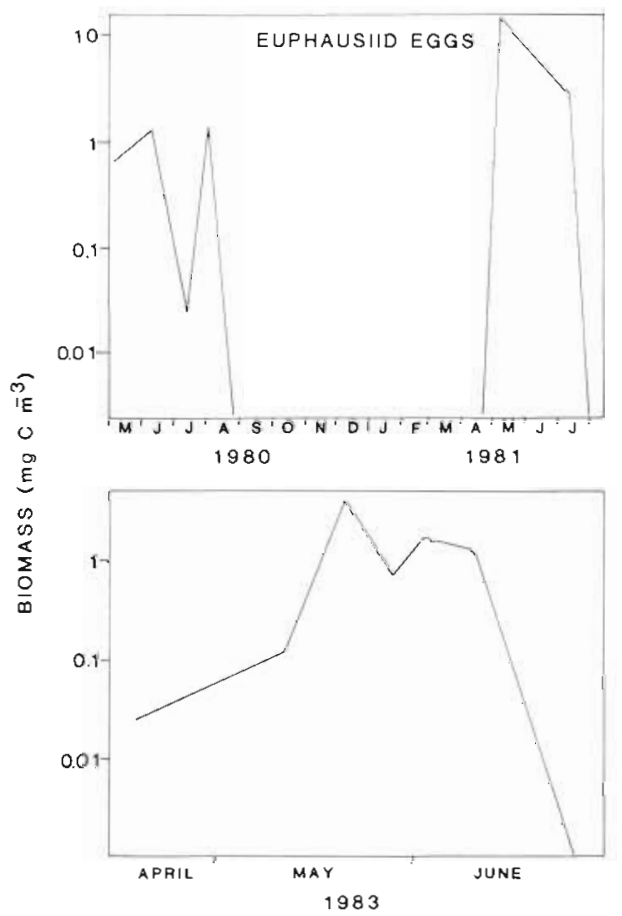

Fig. 8. Temporal changes in biomass for Euphausia pacifica eggs 1980-81, 1983 (data from Larson 1985)

Predation may have also contributed to decreased production by gelatinous predators. In Saanich Inlet, some hydromeduse, i.e. Aequorea victoria and to a lesser extent Stomotoca atra, and scyphomedusae, i.e. Cyanea capillata, prey on medusae and ctenophores, thereby reducing their stocks (Arai \& Jacobs 1980, Mills 1982, Larson 1985). This predation pressure was probably highest during the summer when $A$. victoria was mostly present as adults.

Previous workers (e.g. Greve 1970, Hirota 1974, Kremer 1976, Grice et al. 1980, Deason \& Smayda 1982) have also reported a relation between prey biomass and gelatinous predator standing stocks. However, once predation pressure is high, a negative relation between predator and prey stocks might occur as prey become scarce. Also, once predator population growth declines, secondary predators (e.g. Beroe spp., other medusae, fishes), may have a significant impact (e.g. Anderson 1974, Miller 1974, Burrell \& Van Engel 1976 , Oviatt \& Kremer 1977, Feigenbaum \& Kelly 1984).

Although a correlation (either positive or negative) between the standing stocks of predators and that of 
prey is likely for short-lived species, the relation between prey abundance and predator size is less obvious. There is evidence that small gelatinous predators can obtain their necessary maintenance ration at lower food levels than can larger individuals of the same species. This is because weight-specific ingestion rates are higher for smaller than for larger specimens (Kremer 1976, Walter 1976, Larson 1985), and because large specimens have only a slight metabolic advantage over smaller individuals, owing to weight-specific respiration rates of gelatinous predators being nearly constant (i.e. $b=0.8$ to 1) (Hirota 1972, Kremer 1977, 1982, Larson 1985). Furthermore, since gelatinous predators can actually 'degrow' (i.e. cells decrease in number) when food is scarce, their sizes must be regulated by food supply (Hamner \& Jenssen 1974, Kremer 1976, Grice et al. 1980, Reeve 1980).

\section{Growth}

The growth of gelatinous predators is known to be exponential (Zaika 1972). In situ values for the coefficient of daily exponential population biomass increase (0.1 to 0.3 ) (Table 4 ) are sufficient to enable gelatinous predator populations to grow in biomass rapidly, thereby effectively exploiting fast-growing prey populations. This predator/prey coupling is adaptive in temperate, neritic areas where the spring phytoplankton bloom can be variable (in occurrence, duration, and magnitude) from year to year.

Laboratory-measured exponential growth shows that daily growth coefficient values range up to 0.8 in ctenophores (Reeve \& Walter 1976). Even though laboratory-measured $\mathrm{K}$-values provide insight into maximum growth potentials, such rates rarely occur in

Table 4. Coefficients of daily population biomass increase $(K)$ for gelatinous predators

\begin{tabular}{|c|c|c|c|}
\hline Taxon & $\mathrm{K}$ & Location & Source \\
\hline \multicolumn{4}{|l|}{ Hydromedusae } \\
\hline Aequorea victoria & 0.2 & British Columbia & This paper \\
\hline Aglantha digitale & 0.1 & & \\
\hline \multicolumn{4}{|l|}{ Bougainvillia } \\
\hline multitentaculata & 0.1 & & \\
\hline Euphysa tentaculata & 0.04 & & \\
\hline Mitrocoma cellularia & 0.2 & & \\
\hline Phialidium spp. & 0.2 & & \\
\hline \multicolumn{4}{|l|}{ Proboscidactyla } \\
\hline flavicirrata & 0.1 & & \\
\hline Stomotoca atra & 0.1 & & \\
\hline \multicolumn{4}{|l|}{ Tiaropsis } \\
\hline multicirrata & $0.1^{1}$ & Arctic & Zelickman et al. 1969 \\
\hline \multicolumn{4}{|l|}{ Scyphomedusae } \\
\hline \multirow[t]{4}{*}{ Aurelia aurita } & $0.1^{2}$ & Denmark & Rasmussen 1973 \\
\hline & $0.2^{3}$ & California & Hamner \& Jenssen 1974 \\
\hline & $0.3^{2}$ & Germany & Möller 1980 \\
\hline & $0.1^{2}$ & Black Sea & Shuskina \& Musayeva 1983 \\
\hline Mastigias papua & $0.3^{4}$ & Japan & Sugiura 1963 \\
\hline Rhizostoma octopus & $0.2^{4}$ & Germany & Thiel 1965 \\
\hline \multicolumn{4}{|l|}{ Siphonophores } \\
\hline Muggiaea atlantica & 0.1 & British Columbia & This paper \\
\hline \multicolumn{4}{|l|}{ Ctenophores } \\
\hline Mnemiopsis mccradyi & $0.2^{2}$ & Florida & Baker 1973 \\
\hline \multirow[t]{2}{*}{ Mnemiopsis leidyi } & $0.1^{2}$ & North Carolina & Miller 1970 \\
\hline & $0.3^{2}$ & Rhode Island & Kremer 1976 \\
\hline \multirow[t]{3}{*}{ Pleurobrachia bachei } & $0.1^{2}$ & California & Hirota 1974 \\
\hline & 0.3 & CEPEX ${ }^{5}$ & Reeve \& Walter 1976 \\
\hline & 0.2 & British Columbia & This paper \\
\hline \multirow{4}{*}{$\begin{array}{l}\text { Total gelatinous } \\
\text { zooplankton }\end{array}$} & & & \\
\hline & $0.1^{2}$ & & Huntley 1976 \\
\hline & $0.2^{2}$ & & Guest 1979 \\
\hline & 0.1 & & This paper \\
\hline \multirow{2}{*}{\multicolumn{4}{|c|}{$\begin{array}{l}{ }^{1} \text { Used bell dia to dry weight relation for Phialidium gregarium } \\
{ }^{2} \text { Calculated from data in paper }\end{array}$}} \\
\hline & & & \\
\hline \multicolumn{4}{|c|}{${ }^{3}$ Used bell dia. to dry wt. relation for $A$. aurita } \\
\hline \multicolumn{4}{|c|}{${ }^{4}$ Used log wet wt. $(g)=2.75 \log$ bell dia $(\mathrm{cm})-2.52$} \\
\hline${ }^{5}$ CEPEX mesocosm exl & anich & & \\
\hline
\end{tabular}


Table 5. Gelatinous predator production

\begin{tabular}{|c|c|c|c|c|c|c|c|}
\hline \multirow[t]{2}{*}{ Taxon } & \multicolumn{3}{|c|}{ Net production (mg C) } & \multicolumn{2}{|c|}{$\mathrm{P} / \mathrm{B}$} & \multirow[t]{2}{*}{ Location } & \multirow[t]{2}{*}{ Source } \\
\hline & $\begin{array}{l}\text { Daily (max) } \\
\qquad\left(\mathrm{m}^{-3}\right)\end{array}$ & $\left(\mathrm{m}^{-3}\right)^{\mathrm{Y} \epsilon}$ & $\begin{array}{l}\text { arly } \\
\qquad\left(\mathrm{m}^{-2}\right)\end{array}$ & Daily & $\begin{array}{l}\text { Yearly } \\
(\max )\end{array}$ & & \\
\hline \multicolumn{8}{|l|}{ Hydromedusae } \\
\hline Aglantha digitale & & 5 & $10-260$ & & $3-10$ & Baffin I. & McLaren 1969 \\
\hline Phialidium spp. & 0.4 & $2-8$ & & 0.1 & $10-30$ & British Columbia & This paper \\
\hline \multicolumn{8}{|l|}{ Scyphomedusae } \\
\hline Aurelia aurita & 1 & $40^{1}$ & 1000 & & & $\begin{array}{l}\text { Baltic Sea } \\
\text { Black Sea }\end{array}$ & $\begin{array}{l}\text { Möller } 1980 \\
\text { Shuskina \& Musayeva } 1983\end{array}$ \\
\hline Cyanea capillata & & 1 & 25 & & & Baffin Island & McLaren 1969 \\
\hline \multicolumn{8}{|l|}{ Ctenophores } \\
\hline Beroe ovata & & 3 & 100 & 0.1 & & Baffin Island & McLaren 1969 \\
\hline Mnemiopsis mccradyi & 3 & $60-120$ & $200-400$ & & & Florida & Reeve \& Baker 1975 \\
\hline Mnemiopsis leidyi & $3^{1}$ & $40^{\prime}$ & & & & Rhode Island & Kremer 1975 \\
\hline & $1^{!}$ & $50^{1}$ & & & & North Carolina & Miller 1974 \\
\hline Pleurobrachia bachei & & $25^{1}$ & $500-700$ & 0.02 & & California & Hirota 1974 \\
\hline & 4 & & & 0.4 & & CEPEX $^{2}$ & Reeve \& Walter 1976 \\
\hline & 0.6 & $2-6$ & & 0.2 & $7-20$ & British Columbia & This paper \\
\hline $\begin{array}{l}\text { Total gelatinous } \\
\text { preds. }\end{array}$ & $\begin{array}{l}0.2^{1} \\
0.6^{1} \\
0.4\end{array}$ & $\begin{array}{l}5-10 \\
6^{1} \\
20^{1} \\
5-10\end{array}$ & $\begin{array}{l}150-400 \\
1000^{1}\end{array}$ & 0.1 & 9 & $\begin{array}{l}\text { Baffin Island } \\
\text { British Columbia } \\
\text { British Columbia } \\
\text { British Columbia }\end{array}$ & $\begin{array}{l}\text { McLaren } 1969 \\
\text { Huntley } 1976 \\
\text { Guest } 1979 \\
\text { This paper }\end{array}$ \\
\hline
\end{tabular}

nature because of food limitation, mortality, etc. However, they do show that gelatinous predators have the potential to increase growth rates to very high levels, given sufficient food.

\section{Production}

The accurate measurement of in situ production by short-lived species like hydromedusae and ctenophores, where reproduction (and recruitment) can be continuous over part of the year and cohorts are not evident, is difficult at best, and in most situations impossible (Reeve \& Baker 1975). Although there are few estimates of net production for gelatinous predators (Table 5), they are all within an order of magnitude or less of each other. Daily production values range mostly from 0.01 to $1 \mathrm{mg} \mathrm{C} \mathrm{m}^{-3} \mathrm{~d}^{-1}$, with yearly rates of 10 to $100 \mathrm{mg} \mathrm{C} \mathrm{m}^{-3} \mathrm{yr}^{-1}$. On a unit area basis, values would range from $\sim 0.3$ to $1 \mathrm{~g} \mathrm{C} \mathrm{m}^{-2} \mathrm{yr}^{-1}$; from data in Guest (1979), I estimated that gelatinous predator production in Saanich Inlet could be equal to $\sim 1 \mathrm{~g} \mathrm{C} \mathrm{m}^{-2} \mathrm{yr}^{-1}$. This is similar to the production by Aurelia aurita in the Black Sea (Shushkina \& Musayeva 1983).

Literature values for gelatinous predator production per unit biomass range from 0.01 to 0.4 , on a daily basis, and from 3 to 30 on a yearly basis. These P/B values are similar to those for small copepods (Greze
1978). This is because many gelatinous predators have pulsed seasonal production cycles, like that of their mesozooplankton prey, which are tied to food availability.

Acknowledgements. I thank the Biology Department, University of Victoria for providing shiptime on the MSSV John Strickland. I appreciate the advise and encouragement given by J. Littlepage, L. Hobson, and G. Mackie. I gratefully acknowledge M. Arai, T. Bailey, L. Hobson, P. Kremer, K. Larson, J. Littlepage, M. Youngbluth, and 2 anonymous reviewers for their helpful comments on the manuscript. Financial support, in the form of a post-doctoral fellowship, was provided during preparation of the manuscript by Harbor Branch Institution. This paper is contribution No. 518 of Harbor Branch Foundation.

\section{LITERATURE CITED}

Anderson, E. (1974). Trophic interactions among ctenophores and copepods in St. Margaret's Bay, Nova Scotia. Ph. D. thesis, Dalhousie Univ.

Arai, M. N., Fulton, J. (1973). Diel migration and breeding cycle of Aglantha digitale from two locations in the northeastern Pacific. J. Fish. Res. Bd Can. 30: 551-553

Arai, M. N., Jacobs, J. R. (1980). Interspecific predation of common Strait of Georgia planktonic coelenterates: laboratory evidence. Can. J. Fish. Aquat. Sci. 37 (1): $120-123$

Baker, L. D. (1973). Ecology of the ctenophore Mnemiopsis mccradyi Mayer, in Biscayne Bay, Florida. Rosenstiel School of Marine and Atmospheric Science, Univ, of Miami, Tech. Rept. UM-RSMAS-73016. p. 1-131 
Burrell, V. G., Van Engel, W. A. (1976). Predation by and distribution of a ctenophore Mnemiopsis leidyi A Agassiz, in the York River. Estuar. coast. mar. Sci. 4 235-242

Deason, E. E., Smayda, T. J. (1982). Experimental evaluation of herbivory in the ctenophore Mnemiopsis lejdyi relevant to ctenophore-zooplankton-phytoplankton interactions in Narragansett Bay, Rhode Island, USA. J. Plankton Res. 4 (2): $219-235$

Feigenbaum, D. L., Kelly, M. (1984). Changes in the lower Chesapeake Bay food chain in the presence of the sea nettle Chrysaora quinquecirrha (Scyphomedusae). Mar. Ecol. Prog. Ser. 19: 39-47

Greze, V. N. (1978). Production in animal populations. P.S.Z.N. Mar. Ecol. 4: 85-114

Greve, W. (1970). Okologische Untersuchungen an Pleurobrachia pileus. I. Freilanduntersuchungen. Helgoländer wiss. Meeresunters. 22: 303-325

Grice, G. D., Harris, R. P., Reeve, M. R., Heinbokel, J. F., Davis, C. O. (1980). Large-scale enclosed water-column ecosystems: an overview of Foodweb 1, the final CEPEX experiment. J. mar. biol. Ass. U. K. 60: 401-414

Guest, P. K. (1979). A nitrogen budget for Saanich Inlet, B. C. B. S. Honours thesis, Univ. of Victoria

Heath, W. A. (1977). The ecology and harvesting of euphausiids in the Strait of Georgia. Ph. D. thesis, Univ, of British Columbia

Hamner, W. M., Jenssen, R. M. (1974). Growth, degrowth and irreversible cell differentiation in Aurelia aurita. Am. Zool. 14 (2): 833-849

Herlinveaux, R. H. (1962). Oceanography of Saanich Inlet in Vancouver Island, British Columbia. J. Fish. Res. Bd Can. 19: $1-37$

Hirota, J. (1972). Laboratory culture and metabolism of the planktonic ctenophore Pleurobrachia bachei A. Agassiz. In: Takenouti A. Y. (ed.) Biological oceanography of the North Pacific Ocean. Idemitsu Shoten, Tokyo, p. 465-484

Hirota, J. (1974). Quantitative natural history of Pleurobrachia bachei in La Jolla Bight. Fish. Bull. U. S. 72: 295-335

Huntley, M. E. (1976). Temporal changes in dissolved nutrients, and in the biomass and biochemical composition of phytoplankton and zooplankton in Saanich Inlet, British Columbia. B. S. Honours thesis, Univ. of Victoria

Huntley, M. E., Hobson, L. A. (1978). Medusae predation and plankton dynamics in a temperate fjord, British Columbia. J. Fish. Res. Bd Can. 35: 257-261

Kremer, P. (1975). The ecology of the ctenophore Mnemiopsis leidyi in Narragansett Bay. Ph. D. thesis, Univ, of Rhode Island

Kremer, P. (1976). Population dynamics and ecological energetics of a pulsed zooplankton predator, the ctenophore Mnemiopsis leidyi. In: Wiley, M. L. (ed.) Estuarine processes. Vol. 1. Academic Press, New York, p. $197-215$

Kremer, P. (1977). Respiration and excretion by the ctenophore Mnemiopsis leidyi. Mar. Biol. 44: 43-50

Kremer, P. (1982). Effect of food availability on the metabolism of the ctenophore Mnemiopsis mccradyi. Mar Biol. 71: 149-156

Larson, R. J. (1985). Trophic ecology of gelatinous predators (Cnidaria \& Ctenophora) in Saanich Inlet, Vancouver Is., B. C. Canada. Ph. D. thesis, Univ. of Victoria

Larson, R. J. (in press). Ova production by Hydromedusae from the N. E. Pacific. J. Plankton Res.
Larson, R. J. 1986. Water content, organic content and carbon and nitrogen composition of Medusae from the Northeast Pacific. J. exp. mar Biol. Ecol. 99: 107-120

LeBlond, P. H. (1983). The Strait of Georgia: functional anatomy of a coastal sea. Can. J. Fish. Aquat. Sci. 40: 1033-1063

Mackie, G. O., Mills, C. E. (1983). Use of the Pisces IV submersible for zooplankton studies in coastal waters of British Columbia. Can. J. Fish. Aquat. Sci. 40: 763-776

McLaren, I. A. (1969). Population and production ecology of zooplankton in Ogac Lake, a landlocked fjord on Baffin Island. J. Fish. Res. Bd Can. 26: 1485-1559

Miller, R. J. (1970). Distribution and energetics of an estuarine ctenophore population, Mnemiopsis leidyi. $\mathrm{Ph}$. D. thesis, Univ. of South Carolina

Miller, R. J. (1974). Distribution and biomass of an estuarine ctenophore population, Mnemiopsis leidyi (A. Agassiz). Chesapeake Sci. 15 (1): 1-8

Mills, C. E. (1982). Patterns and mechanisms of vertical distribution of medusae and ctenophores. Ph. D. thesis, Univ. of Victoria

Moller, H. (1980). Population dynamics of Aurelia aurita medusae in Kiel Bight, Germany (FRG). Mar. Biol. 60: 123-128

Oviatt, C. M., Kremer, P. M. (1977). Predation on the ctenophore Mnemiopsis leidyi by the butterfish Peprillus tricanthus, in Narragansett Bay, Rhode Island. Chesapeake Sci. 18: 236-240

Pickard, G. L. (1961). Oceanographic features of inlets in the B. C. mainland coast. J. Fish. Res. Bd Can. 18: 907-999

Rasmussen, E. (1973). Systematics and ecology of the Isefjord marine fauna (Denmark). Ophelia 11: 1-90

Reeve, M. R. (1980). Comparative experimental studies in the feeding of chaetognaths and ctenophores. J. Plankton Res. 2: $381-393$

Reeve, M. R. Baker, L. D. (1975). Production of two planktonic carnivores (chaetognath and ctenophore) in south Florida inshore waters. Fish. Bull. U. S. 73 (2): 238-247

Reeve, M. R., Walter, M. A. (1976). A large scale experiment on the growth and predation potential of ctenophore populations. In: Mackie, G. O. (ed.) Coelenterate ecology and behavior. Plenum, New York, p. 187-199

Shushkina, E. A., Musayeva, E. I. (1983). The role of jellyfish in the energy system of the Black Sea plankton communities. Oceanology 23 (1): 92-96

Sugiura, Y (1963). On the life-history of the rhizostome medusae. I. Mastigias papua. Annotnes zool. jap. 36 (4): 194-202

Thiel, M. E. (1965). Untersuchungen über die Herkunft, das Auftreten, das Wachstum und die Fortpflanzung von Rhizostoma octopus L. Ag. im Elbmündungsgebiet. Abhandl. u. Verhdl. der Natur. Ver. in Hamburg N.F. 10: $59-88$

Thomson, R. E. (1981). Oceanography of the British Columbia coast. Can. Spec. Publ. Fish. Aquat. Sci. 56: 1-291

Walter, M. A. (1976). Quantitative observations on the nutritional ecology of ctenophores with special references to Mnemiopsis mccradyi. M. S. thesis, Univ. of Miami

Zaika, V E. (1972). Growth of ctenophores and medusae. Zool. Zh. 51: 179-188

Zelickman, E. A., Gelfand, V. I., Shifrin, M. A. (1969). Growth, reproduction and nutrition of some Barents Sea hy dromedusae in natural aggregations. Mar. Biol. 4 $167-173$ 